\title{
Lead Pollution Remanence in an Urban River System: A multi-scale temporal and spatial study
}

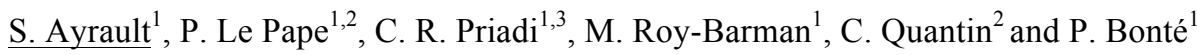 \\ ${ }^{1}$ Laboratoire des Sciences du Climat et de l'Environnement (LSCE/IPSL), UMR 1572 (CEA/CNRS/UVSQ), Domaine \\ du CNRS, Avenue de la Terrasse, bat 12,91198 Gif-sur-Yvette, FRANCE, sophie.ayrault@lsce.ipsl.fr \\ 2 Interactions et Dynamique des environnements de Surface (IDES), UMR 8148 (UPS - CNRS), Bâtiment 504, Campus \\ universitaire d'Orsay, 91405 Orsay Cedex, France, pierre.le-pape@u-psud.fr \\ ${ }^{3}$ Civil Engineering Department, Engineering Faculty, Universitas Indonesia, UI Depok Campus, Depok 16424 - \\ INDONESIA, cindy.priadi@eng.ui.ac.id
}

\begin{abstract}
This work aims at studying the fate of sediments contaminated with tetraethyl $\mathrm{Pb}$ from leaded gasoline using a two-dimension upscaling approach, from a small urban subcatchment, the Orge River (900 $\left.\mathrm{km}^{2}\right)$ to the whole Seine River basin $\left(64700 \mathrm{~km}^{2}\right)$, in France. In France, the leaded gasoline reduction started in 1986 and leaded gasoline was completely banned after 2000. This work aims at assessing whether the ban of leaded gasoline is related to changes in $\mathrm{Pb}$ contamination sources of these river suspended sediment particles (SPM) and bed sediment. Sediment cores and samples collected in the course of previous research projects of the Seine River contamination were used as temporal archives. The study of the isotopic lead ratio showed the fast decrease of the contamination of urban river suspended particulate matter due to the "gasoline" lead source from 2000 to 2011. This source mostly disappeared in the SPM from the Seine River basin that includes urban areas but also agricultural and industrial activities. Nevertheless, it is still present in the small urban catchment of the Orge River. The results on bed sediments showed a different pattern, where the "gasoline" source is still active in densely populated areas, either in the Seine River in the $20 \mathrm{~km}$ downstream Paris, or along the Orge River.
\end{abstract}

Key words: Lead, urban river, isotopes, pollution, anthropogenic sources

\section{Introduction}

Lead $(\mathrm{Pb})$ represents one of the major metallic contaminants of the Seine River. Dredged sediments are characterized by such high $\mathrm{Pb}$ contents that they are classified in the "moderated to highly contaminated sediment" category (Meybeck et al., 2007). Although the release of $\mathrm{Pb}$ into the environment has been strongly reduced, the lead contamination of the sediments on the downstream part of the Seine River is still three times higher than the geochemical background, i.e. $20 \mathrm{mg} \mathrm{kg}^{-1}$ (Thévenot et al., 2007). The Pb concentration measured in the river suspended particles clearly reveals the high level of contamination of the river. However, it does not provide any information on the different sources of this contamination. The $\mathrm{Pb}$ isotopic composition represents a powerful tool to evaluate the different sources of $\mathrm{Pb}$ (natural, industrial, leaded gasoline) that are released into the environment (Monna et al., 2000; Shotyk et al., 1998). This work aims at studying the fate of sediments contaminated with tetraethyl $\mathrm{Pb}$ from leaded gasoline using a two-dimension upscaling approach, from a small urban subcatchment, the Orge River, to the whole Seine River basin, and involving temporal trends study based on (1) samples repository, and (2) dated sediment cores.

\section{Materials and Methods}

The studied sites were located in the Seine River basin, a sedimentary basin in the north of France, flowing through the Greater Paris Region. Upstream its estuary, the Seine River drains an area of $64700 \mathrm{~km}^{2}$ with an average density of 215 people $/ \mathrm{km}^{2}$, an ideal example of a highly urbanised basin as it hosts $25 \%$ of French agriculture, $30 \%$ of French industry and $23 \%$ of French population. Previous studies have indicated a significant metal load within the watershed, representative of a multi-metal contamination in an urban catchment (e.g., Thévenot et al., 2007).

At the scale of the whole Seine River basin, the 
sampling scheme aims to distinguish the impacts of two sources of anthropogenic influence to the Seine River (Priadi et al. 2011a). The first source is the wastewater treatment plant WWTP Seine-Aval treating around 1.7 million $\mathrm{m}^{3}$ per day, $30 \mathrm{~km}$ downstream Paris. The second is the area of Greater Paris, including the most densely urbanized area in the region with more than 3700 inhabitants $/ \mathrm{km}^{2}$. Treated municipal wastewater from smaller units and urban runoff are the major identified metal sources to the river in this area. The first sampling site is located at Marnay-sur-Seine, situated far upstream on the Seine River (Priadi et al. 2011b). It was chosen to represent a site non-affected by the Greater Paris region, where the Seine is a 6 Strahler order river, and the population density upstream Marnay is only 15-30 inhabitants $/ \mathrm{km}^{2}$. The second site is located at Bougival, $40 \mathrm{~km}$ downstream of Paris city (Strahler order 7). It was chosen to study the impact of Greater Paris without the influence of the major WWTP Seine-Aval. Another 40 $\mathrm{km}$ further downstream site, Triel-sur-Seine, was selected to demonstrate the influence of Greater Paris region including all its inputs to the river. The Triel station is situated downstream of the confluence of the Seine River with one of its major tributaries, the Oise River, making it a Strahler order 8. Sampling was performed from October 2008 to October 2009. Unless mentioned otherwise, suspended particle matter (SPM) is collected around the $20^{\text {th }}$ of each month. Bed sediments were collected in the course of the National River Network (RNB) in 2007-2009, at sites inside Paris and in the 10 $\mathrm{km}$ downstream Paris.

The Orge River sub-catchment is located in the upper part of the hugely anthropized Seine River watershed, and drains an area of $950 \mathrm{~km}^{2}$ with a density ranging between 200 people $/ \mathrm{km}^{2}$ upstream to 8000 people $/ \mathrm{km}^{2}$ downstream. Sampling campaigns were done in 2001 and in 2010/2011 along the Orge River, including two of its tributaries, to exhibit spatio-temporal trends of urban contamination at the scale of this densely populated small catchment. SPM and bed sediments (10 first centimeters) were sampled.

Lead isotopic data in dated sediment cores sampled in different parts of the whole Seine River catchment (Ayrault et al., 2012) will be used in the discussion. Endmembers used in this study for lead ${ }^{206} \mathrm{~Pb} /{ }^{207} \mathrm{~Pb}$ isotopic ratios were constructed according to Elbaz-Poulichet et al. (1986) for the natural lead background of Paris region (1.2007 \pm 0.0011$)$, to Véron et al. (1999) for gasoline lead $(1.08 \pm 0.02)$, and to Ayrault et al. (2012) for urban lead in the Paris watershed $(1.154 \pm 0.002)$.

\section{Results and Discussion}

The isotopic trends observed in the most downstream Seine River cores represent the temporal variation of the different lead source contributions to suspended particulate matter (SPM) over the past 100 years. To concentrate on the last decades, the ${ }^{206} \mathrm{~Pb} /{ }^{207} \mathrm{~Pb}$ ratio decreases to $1.144 \pm 0.003$ between 1960 and 1986/1989, evidencing the influence of leaded gasoline on the Seine River pollution. Then, starting from 1986/1989 up to the early 2000 's, the ${ }^{206} \mathrm{~Pb} /{ }^{207} \mathrm{~Pb}$ ratio increases up to $1.166 \pm$ 0.003 in 2003 . The decrease of leaded gasoline influence on the Seine River pollution observed from the end of the 1980 is coupled to a general decrease of the $\mathrm{Pb}$ concentration. This last point is explained by the improved treatment of waste water at the scale of the whole Seine River basin, coupled to the decreased of the volumes of untreated water released directly to the river. Considering the respective signature of the natural lead $\left({ }^{206} \mathrm{~Pb} /{ }^{207} \mathrm{~Pb}=1.2007 \pm 0.0011\right)$ and the signature of urban lead $\left({ }^{206} \mathrm{~Pb} /{ }^{207} \mathrm{~Pb}=1.154 \pm 0.002\right)$ defined by the waste water treatment plant effluent (Ayrault et al., 2012), we calculate that the lead in the today Seine River SPM $\left({ }^{206} \mathrm{~Pb} /{ }^{207} \mathrm{~Pb}=1.166 \pm 0.004\right)$ is constituted of $30 \%$ of natural lead and $70 \%$ of urban lead. The study of SPM sampled monthly (2008-2009) in the downstream part of the Seine River showed that the lead signature is very stable $\left({ }^{206} \mathrm{~Pb} /{ }^{207} \mathrm{~Pb}=1.1627 \pm 0.0025, \mathrm{n}=9\right.$, matching the signature determined for the upper section of the core) over one hydrological year. In contrast, the study of bed sediment showed variable signature (from ${ }^{206} \mathrm{~Pb} /{ }^{207} \mathrm{~Pb}=$ $1.138 \pm 0.003$ to $1.165 \pm 0.002$ ) coupled to very variable lead content, the highest lead content being associated to the highest gasoline lead contribution to the isotopic ratio.

For the Orge River catchment, lead concentrations were found to be 2 to 6 times higher in SPM than the natural local background (Fig. 1). The lead concentration is a function of the urbanization density. The trends of lead isotopic signature of SPM from 2001 to 2010/2011 were similar to the trends observed in the whole Seine River basin. Indeed, the 2010/2011 SPM samples $\left({ }^{206} \mathrm{~Pb} /{ }^{207} \mathrm{~Pb}=1.165 \pm 0.008, \mathrm{n}=28\right)$ were close to the signature determined for the Rio Tinto ores $\left({ }^{206} \mathrm{~Pb} /{ }^{207} \mathrm{~Pb}\right.$ $=1.163 \pm 0.002)$ whatever the sampling site and the hydrological conditions. Indeed, the Rio Tinto ore signature may be the best source estimation for $\mathrm{Pb}$ that accumulated over centuries in the Seine River basin and may be called "historical" Parisian lead (Ayrault et al., 2012). The influence of the local background lead $\left({ }^{206} \mathrm{~Pb} /{ }^{207} \mathrm{~Pb}=1.20\right)$ endmember could explain that the ${ }^{206} \mathrm{~Pb} /{ }^{207} \mathrm{~Pb}$ ratio are in average higher at the most upstream, less urbanized, sites $\left({ }^{206} \mathrm{~Pb} /{ }^{207} \mathrm{~Pb}=1.171 \pm 0.008\right.$, $\mathrm{n}=12$ ).

We note that samples with $\mathrm{Pb}$ concentration close to the natural level have a ${ }^{206} \mathrm{~Pb} /{ }^{207} \mathrm{~Pb}$ ratio significantly below the natural ${ }^{206} \mathrm{~Pb} /{ }^{207} \mathrm{~Pb}$ ratio. It raises the possibility that the local natural signature in the Orge River watershed may be different than the signature determined by Elbaz-Poulichet et al. (1986) for the whole Seine River basin. Alternatively, it might represent a pervasive contamination by the anthropogenic $\mathrm{Pb}$.

The most downstream and urbanized sites were also influenced by the third endmember: gasoline lead $\left({ }^{206} \mathrm{~Pb} /{ }^{207} \mathrm{~Pb}=1.08\right)$. At the confluence of the Seine River and the Orge River, the Orge River SPM has an isotopic ratio similar to the urban lead signature (Fig. 1). The changes in lead isotopic signature observed from 2001 to 2010/2011 were not coupled to any changes in SPM lead concentration. In this small urban catchment, untreated runoff waters are released directly to the river since early 2000 's. In agreement with the signature observed, the 
gasoline lead source would have been replaced with lead issued from urban infrastructure. The study of bed sediment (2010/2011) showed a strong variability in the results obtained for a same sampling site, but sampled at different periods during the year. This could be due to the relatively low lead concentration in the sediments compared to SPM, associated to the variability of lead speciation in these bed sediments as a function of particles origins. Indeed, fluxes of particles could change according to meteorological conditions and river hydrodynamics. As a consequence, proportions in the fluxes of lead-bearing particles could evolve between urban and natural origins. Otherwise, as the bed sediments were sampled at the surface of the bed column, the influence of the lead gasoline endmember was not identified in the Orge River, probably due to a quick turnover of sediment stocks in this catchment, which is also suggested by results obtained on SPM over the last decade. Other results on bed sediments showed that the isotopic signatures were changing for the different size grain fractions of the sediments, showing that the lead bearing particles of natural origin were mainly present in the fine fraction $(<50 \mu \mathrm{m})$, whereas anthropogenic originated particles were found in the coarse fraction $(>$ $50 \mu \mathrm{m})$. These results are consistent with the detection in electron microscopy of large size $(50-200 \mu \mathrm{m})$ lead containing alloys, coming from urban infrastructures. Lead ${ }^{206} \mathrm{~Pb} /{ }^{207} \mathrm{~Pb}$ ratio was also measured in "road deposit sediments", corresponding to sediments recovered in a road gutter at a strongly urbanized site $\left(8000 \mathrm{inh} / \mathrm{km}^{2}\right)$, and the result $\left({ }^{206} \mathrm{~Pb} /{ }^{207} \mathrm{~Pb}=1.144 \pm 0.003\right.$, in 2011$)$ revealed the remanence of leaded gasoline. This is probably due to the persistence of this pollution in places where urban dust accumulated over decades, and was progressively leached by rain runoff over long period of time.

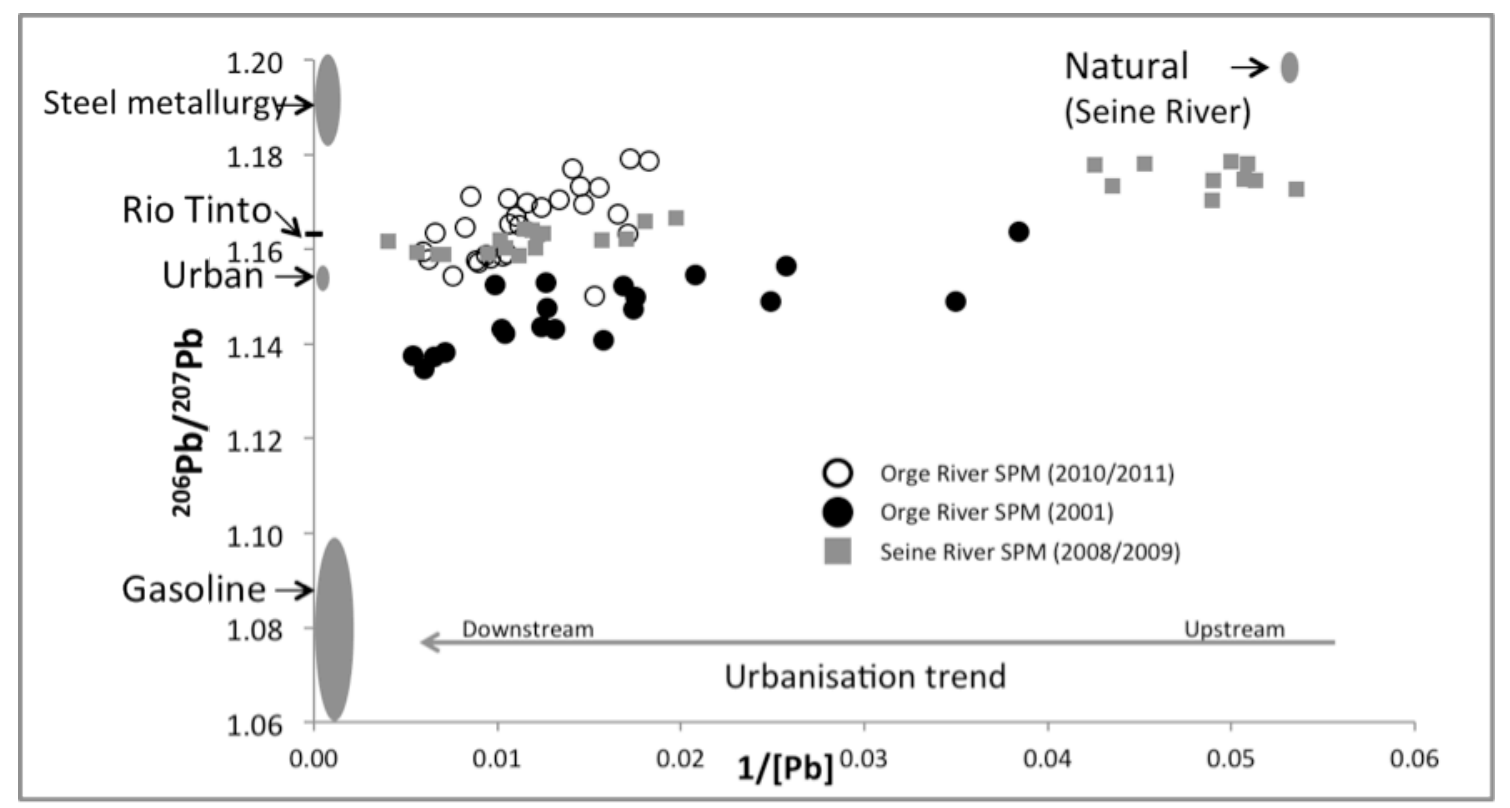

Fig. 1. Evolution of the lead isotopic ratio ${ }^{206} \mathrm{~Pb} /{ }^{207} \mathrm{~Pb}$ of the Seine River SPM ( $2008-2009$ sampling campaigns) and of the SPM in the Orge River catchment ((O)2010/2011 sampling campaigns. (•)2001 sampling campaigns).

\section{Conclusion}

The study of the isotopic lead ratio showed the fast decrease of the contamination of urban river suspended particulate matter due to the "gasoline" lead source after the banishment of gasoline leaded additives (2000). This source mostly disappeared in the SPM from a large catchment that includes urban areas but also agricultural and industrial activities. Nevertheless, it is still present in small urban catchment. The results on bed sediments showed a different pattern, where the "gasoline" source is still active in densely populated areas. The persistence of the contamination in bed sediments seems to be related to a grain size effect. This contamination would originate from outdoor dust and metallic structures, through release of untreated runoff waters to the river.

Besides these conclusions, these results showed that the multi-scale temporal and spatial scheme developed here is a powerful strategy to study the heavy metal transport in urban environment.

\section{Acknowledgements}

The authors would like to thank Louise Bordier (LSCE) for sampling, and for analytical assistance with ICP-MS measurements and Rémy Pichon (IDES) for SEM-EDX observations (Orge River samples). This work was supported by the EC2CO/CYTRIX-CNRS/INSU Program, by PIREN Seine program and by the French Ministry of National Education and Research. 


\section{References}

Ayrault S, Roy-Barman M, Le Cloarec MF, Priadi C, Bonté P, Göpel C. Lead contamination of the Seine River, France: geochemical implications of a historical perspective. Chemosphere 2012, 97:902-910.

Elbaz-Poulichet F, Holliger P, Martin JM, Petit D. Stable lead isotopes ratios in major French rivers and estuaries. Sci. Total Environ. 1986, 54:61-76.

Meybeck M, Lestel L, Bonté P, Moilleron R, Colin JL., Rousselot, O., et al. Historical perspective of heavy metals contamination $(\mathrm{Cd}, \mathrm{Cr}, \mathrm{Cu}, \mathrm{Hg}, \mathrm{Pb}, \mathrm{Zn})$ in the Seine River basin (France) following a DPSIR approach (1950-2005). Sci. Total Environ. 2007, 375:204-31.

Monna F, Clauer N, Toulkeridis T, Lancelot J R. Influence of anthropogenic activity on the lead isotope signature of Thau Lake sediments (southern France): origin and temporal evolution. Appl. Geochem. 2000, 15:1291-1305.

Priadi C, Bourgeault A, Ayrault S, Gourlay-Francé C, Tusseau-Vuillemin M-H, Bonté P, Mouchel J-M.
Spatio-temporal variability of solid, total dissolved and labile metal: passive vs discrete sampling evaluation in river metal partitioning. Journal of Environmental monitoring, 2011a, 13:1470-1479.

Priadi C, Ayrault S, Pacini S, Bonté P. Urbanization impact on metal mobility in riverine suspended sediment: Role of metal oxides. International Journal of Environmental Science and Technology, Int. J. Environ. Sci. Tech. 2011b, 8 (1):1-18.

Shotyk W, Weiss D, Appleby P, Cheburkin A, Frei R, Gloor M, Kramers J, Reese S, Van Der Knapp W. History of atmospheric lead deposition since 12,370 14C yr BP from peat bog, Jura Mountains, Switzerland. Science 1998, 281:1635-40.

Thévenot DR, Moilleron R, Lestel L, Gromaire MC, Rocher V, Cambier P, Bonté P, Colin JL, de Pontevès C, Meybeck M. Critical budget of metal sources and pathways in the Seine River basin (1994-2003) for Cd, Cr, Cu, Hg, Ni, Pb and Zn. Sci. Total Environ. 2007, 375:180-203.

Véron A, Flament P, Bertho ML, Alleman L, Flegal R, Hamelin B. Isotopic evidence of pollutant lead sources in Northwestern France. Atmos. Environ. 1999, 33:3377-88. 